
\title{
25 Research Soure \\ Ethnic Disparities in Presentation, Management and Outcome of Testicular Cancer
}

\section{Li Sian Low ( $\nabla$ low130@hotmail.com )}

Urology Department, Waikato District Health Board, Hamilton, New Zealand https://orcid.org/00000002-0507-1356

\section{Shiva Nair}

Waikato DHB

\section{Michael Holmes}

Waikato District Health Board

\section{Research}

Keywords: Testicular Cancer, Incidence, Ethnicity, Maori, Equity

Posted Date: November 18th, 2020

DOl: https://doi.org/10.21203/rs.3.rs-106409/v1

License: (c) (i) This work is licensed under a Creative Commons Attribution 4.0 International License. Read Full License 


\section{Abstract}

Background: The incidence rate of testicular cancer in New Zealand (NZ) is one of the highest in the world. Compared to other ethnic groups in NZ, Maori have been reported as having the highest incidence and cancer specific mortality. We aim to investigate whether disparities in presentation and management of the disease exist between European and Maori males within a large tertiary referral centre in NZ.

Methods: A retrospective cohort study was performed from January 2009 to July 2019. Ethnicity was self-defined. Tumour characteristics and mortality data were recorded. Time from onset of symptoms to surgical treatment was measured. Exclusion criteria were paratesticular tumour and non-Maori and nonEuropean ethnicity.

Results: 113 patients underwent radical orchidectomy within the time period. Maori had a significantly higher risk of developing testicular cancer compared to Europeans (RR 2.19, 95\% Cl $1.47-3.24, p=0.01$ ). There were no significant differences in cancer specific or overall survival. The mean time duration between symptom onset and first specialist assessment (FSA) was 189 days for Maori and 128 days for European $(p=0.12)$. Once FSA is done, there was no difference in time to operating theatre. However, Maori were less likely to attend follow up appointments ( $87 \%$ vs $98 \%, p=0.02)$.

Conclusion: Maori males are more likely to develop testicular cancer in this study. Although no difference in cancer specific survival was seen, there was a large difference in time from symptom onset to referral to specialist review and the probability of attending follow up appointments.

\section{Introduction}

There has been a disproportionately greater increase in testicular cancer incidence among European countries compared to developing countries, with New Zealand (NZ) having the highest overall agestandardized incidence rates. Between 1983 and 2002 the standardized incidence rate for NZ has shown a significant increase from 5.9 to 7.8 per 100,000 men. However, the age-standardized mortality rates have shown a decline in both NZ and Australia[1].

In NZ, the indigenous Maori population have higher cancer diagnosis and mortality rates and as part of this testicular malignancy is more prevalent in Maori than non-Maori[2]. This is contrary to other OECD countries where European males have five times higher risk for testicular cancer than other ethnicities. Socio-economic factors in combination with genetic predisposition may contribute to the disparity[3].

Healthcare disparities can cause limitations in the overall quality and delivery of healthcare for the whole population. Disparities in healthcare have been described in various NZ-based studies. Within NZ, Maori patients have been noted to have lower rapport with doctors, leading to lower consultations with health professionals and poor compliance with investigations. 
The primary aim of this study is to investigate and compare the incidence rates of testicular cancer among the European and Maori communities in a tertiary referral hospital, where all the testicular cancers are managed within the region. The secondary aim was to analyse the health care utilization by the major ethnic groups in management of the disease was examined.

\section{Materials And Methods}

\section{Study design and participants}

We performed a retrospective cohort study on all patients who underwent radical orchidectomy for testicular cancer from January 2009 to July 2019 at Waikato Hospital. All patients had their procedure performed in Waikato Hospital, New Zealand. Patients were predominantly referred to the Department of Urology of Waikato Hospital by their general practitioners (GP).

Testicular tumours were confirmed clinically through a physical examination, a scrotal ultrasound scan and serum tumour markers. A computed tomography (CT) was performed on all patients with confirmed malignancy to stage for metastatic disease. Participants were excluded if the tumour was paratesticular in origin or if the histology was insufficient to allow tumour classification. Patients who did not identify their ethnicity as either European or Maori were also excluded.

This study has been approved and registered with the Waikato District Health Board, Hamilton, New Zealand.

\section{Outcomes}

\section{Patient Characteristics and Ethnicity}

The ethnicity data for our cohort was obtained based on each individual's self-identified affiliation with an ethnic group, via the hospital/primary care patient registration form. For individuals who identify with both ethnic groups (European and Maori), they are categorised primarily as NZ Maori in our cohort. The incidence rate for testicular cancer was expressed per 100,000 person-years, as well as serum tumour markers.

\section{Tumour Characteristics}

Tumour type was categorized based on the histology data following orchidectomy. Testicular tumours were classified as either germ cell or non-germ cell. Germ cell tumours were classified as seminoma or non-seminoma. Mixed germ cell tumours were classified as non-seminomas. Tumour pathologic $T$ staging was identified from the final histology report.

\section{Mortality}


Patient mortality data was obtained via medical records throughout the study period. We included all causes of death, to determine all-cause mortality and only testicular cancer related mortality. All-cause mortality is defined as death regardless of cause.

\section{Time to First Specialist Assessment (FSA) and Treatment}

The first specialist appointment (FSA) is defined as the initial appointment with the urologist after GP referral. Data around duration of onset of symptoms to presentation (to their GP), time from referral (by the GP) to being seen in the FSA clinic, time from the FSA to orchidectomy and time from ultrasound to orchidectomy were collected.

Statistical analysis was performed with SPSS (IBM Corp. Released 2017. IBM SPSS Statistics for Windows, Version 25.0). Level of significance used for the tests was 0.05 .

\section{Results}

\section{Baseline Characteristics}

We identified 122 patients, aged 17 to 73, who underwent radical orchidectomy from January 2009 to July 2019. After application of the exclusion criteria (paratesticular tumour, $n=1$ and insufficient histology to allow tumour classification, $n=2$, Asian ethnicity, $n=2$, non-identified ethnicity, $n=4), 113$ patients files were used for analysis. The majority of our cohort had no other medical comorbidities.

Based on population data from the $2013 \mathrm{NZ}$ census[4], the observed incidence rate of testicular cancer in the Waikato Region in European males was 5.6/100,000 person-years, compared to $12.3 / 100,000$ personyears in Maori males (Fig. 1). Maori men had a significantly higher risk of developing testicular cancer compared to Europeans (RR 2.19,95\% Cl 1.47-3.24, $p=0.01$ ). There was no significant difference in the age of diagnosis between the ethnicities.

Histological findings revealed that classical seminomas were the predominant histological type in both groups (60\% in Maori vs $72 \%$ in Europeans). Almost all patients $(n=100)$ had a pathologic stage of T2 or less. Between the two groups, there were no significant differences in tumour histology, T stage or AJCC risk category (Table 1). The post orchidectomy treatment options were also similar. 
Table 1

Tumour characteristics, including tumour type, disease stage, AJCC (American Joint Committee on Cancer) risk stratification and Post Orchidectomy Treatment

\begin{tabular}{|c|c|c|c|}
\hline & $\begin{array}{l}\text { European }(\mathrm{n}= \\
68)\end{array}$ & Maori $(n=39)$ & $p$ value \\
\hline Mean Age (years) & 38 & 36.2 & 0.26 \\
\hline Seminoma $(n)$ & $41(60.2 \%)$ & $28(72.8 \%)$ & 0.21 \\
\hline Non - seminoma $(n)$ & 27 & 11 & 0.25 \\
\hline $\begin{array}{l}\text { Pathological stage } \\
\text { - pT1 } \\
\text { • pT2 } \\
\text { • pT3 } \\
\text { • pT4 }\end{array}$ & $\begin{array}{l}49(72.1 \%) 16 \\
30\end{array}$ & $\begin{array}{l}27(69.2 \%) 11 \\
10\end{array}$ & $\begin{array}{l}0.760 .590 .63 \\
\text { NA }\end{array}$ \\
\hline $\begin{array}{l}\text { AJCC risk: } \\
\cdot \text { Low } \\
\cdot \text { Intermediate } \\
\cdot \text { High }\end{array}$ & 5738 & 3531 & 0.370 .480 .14 \\
\hline Post Orchidectomy Treatment & 16 & 8 & 0.77 \\
\hline - Surveillance & 48 & 28 & 0.73 \\
\hline - Chemotherapy & 4 & 2 & 0.89 \\
\hline - Radiation with/out & 5 & 1 & 0.33 \\
\hline $\begin{array}{l}\text { Chemotherapy } \\
\text { - Retroperitoneal Lymph Node Dissection } \\
\text { (RPLND) }\end{array}$ & 0 & 1 & $\mathrm{~N} / \mathrm{A}$ \\
\hline - DNA followup & & & \\
\hline
\end{tabular}

Mortality

Death was observed in eight patients from our cohort, with five all-cause mortality and three cancerspecific mortality (Table 2, Fig. 2). There was no significant difference in overall survival or diseasespecific survival between both ethnicities. 
Table 2

Cause of death

\begin{tabular}{|lllllll|}
\hline Patient & Ethnicity & $\begin{array}{l}\text { Age at } \\
\text { Diagnosis }\end{array}$ & $\begin{array}{l}\text { Time to Death } \\
\text { (months) }\end{array}$ & Histology & Stage & $\begin{array}{l}\text { Cause of } \\
\text { Death }\end{array}$ \\
\hline 1 & European & 19 & 16 & $\begin{array}{l}\text { High risk Non- } \\
\text { Seminoma }\end{array}$ & 3 & $\begin{array}{l}\text { Cancer- } \\
\text { Related }\end{array}$ \\
\hline 2 & European & 49 & 12 & $\begin{array}{l}\text { Intermediate risk } \\
\text { Seminoma }\end{array}$ & 3 & $\begin{array}{l}\text { Myocardial } \\
\text { Infarction }\end{array}$ \\
\hline 4 & European & 22 & 29 & $\begin{array}{l}\text { High risk Non- } \\
\text { Seminoma }\end{array}$ & 3 & $\begin{array}{l}\text { Cancer- } \\
\text { Related }\end{array}$ \\
\hline 5 & European & 47 & 28 & $\begin{array}{l}\text { Low risk } \\
\text { Seminoma }\end{array}$ & 1 & $\begin{array}{l}\text { Pulmonary } \\
\text { Embolism }\end{array}$ \\
\hline 6 & European & 38 & 15 & $\begin{array}{l}\text { High risk Non- } \\
\text { Seminoma }\end{array}$ & 3 & $\begin{array}{l}\text { Cancer- } \\
\text { Related }\end{array}$ \\
\hline 7 & European & 28 & 18 & $\begin{array}{l}\text { Low risk Non- } \\
\text { Seminoma }\end{array}$ & 2 & $\begin{array}{l}\text { Cancer- } \\
\text { Related }\end{array}$ \\
\hline 8 & European & 21 & 8 & $\begin{array}{l}\text { High risk Non- } \\
\text { Seminoma }\end{array}$ & 3 & $\begin{array}{l}\text { Cancer- } \\
\text { Related }\end{array}$ \\
\hline Maori & 39 & 37 & $\begin{array}{l}\text { Low risk } \\
\text { Seminoma }\end{array}$ & 1 & $\begin{array}{l}\text { Cancer- } \\
\text { Unrelated }\end{array}$ \\
\hline
\end{tabular}

\section{Time to First Specialist Appointment (FSA) and Treatment}

The mean duration between symptom onset and FSA was 189 days for Maori and 128 days for European $(p=0.12$, Table 3$)$. There was trend to towards difference in time to FSA between Maori and European (13 vs 8 days, $p=0.08$ ). Once FSA is done, there was no difference in time to operating theatre. However, Maori were less likely to attend follow up appointments ( $87 \%$ vs $98 \%, p=0.02)$.

Table 3

Differences in presentation and follow up in each ethnicity

\begin{tabular}{|llll|}
\hline & European & Maori & $p$ value \\
\hline Mean time to FSA from onset of symptoms (days) & 127.6 & 189.4 & 0.12 \\
\hline Mean time to FSA from referral (days) & 8.2 & 12.6 & 0.08 \\
\hline Mean time to orchidectomy from FSA (days) & 8.8 & 7.6 & 0.43 \\
\hline Mean time to orchidectomy from ultrasound (days) & 16.5 & 18.9 & 0.42 \\
\hline Did not attend follow up $(n)$ & $1(2 \%)$ & $5(13 \%)$ & 0.02 \\
\hline
\end{tabular}

\section{Discussion}


We have described the epidemiology of testicular cancer in the Waikato region, NZ. Our study is in concordance with previous NZ-based published findings by Sarfati[3] and Gurney[5]; Maori males were more likely to be diagnosed with testicular cancer compared to other ethnicities (RR 1.51 and RR 1.8, respectively). Gurney and colleagues also described higher mortality rates among Maori males with the disease. We were not able to find a similar mortality discrepancy likely due to smaller number of events.

A global study on the incidence of testicular cancer published in 2003 similarly observed an increased incidence in the Maori population when compared to the non-Maori population (6.8/100,000 vs $5.3 / 100,000)$. They also identified that NZ born residents living in Australia have significantly higher risk for testicular cancer compared to Australians (7.9/100,000 vs 3.3/100,000 person-years)[6].

One of the risks of developing testicular cancer is cryptorchidism[7]. Maori males have higher rates of cryptorchidism than Europeans, and they receive treatment later[8]. Delayed orchidopexy has been linked to slight increase in risk of testicular cancer[9]. However, cryptorchidism does not seem to be the sole aetiology. There has to be a complex interplay of environmental, socio-economic and genetic factors to lead to such a pronounced discrepancy in incidence. A prospective case-control study is underway to examine this[10].

The Royal Australasian College of Surgeons (RACS) has identified that inequitable access to surgical procedures is a significant problem within Australia and NZ. Recently, there is an impetus to explore and understand the causes of disparities in surgical diseases and incidence, with the goal of improving the health outcomes of ethnic minorities. Several explanations have been put forward to describe the health disparities among the Maori population. Access to healthcare and discrimination are potential factors for disparity. There is increasing evidence that Maori are less likely to be referred to specialist services and receive lower than expected levels of quality hospital care[11]. A recently published systematic review in the ANZ Journal of Surgery described the presence of significant disparities with regards to patient demographics, surgical treatment and postoperative complications. It drew to attention that Maori were less likely to receive curative treatment, have higher rates of comorbidities and have higher deprivation rates[12].

In our study, we found Maori men may have had longer onset of symptoms (189 vs $128, p=0.12)$ and longer duration to be seen by at FSA from GP referral ( 13 vs 8 days, $p=0.08)$. The delay in presentation may be due to cultural issues of genital examination. The department schedules the next available appointment convenient to the patient, and the delay from GP referral to FSA may be a combination of socio-economic factors such as transportation, leave from work; and education about disease (importance of earliest FSA). However, once seen by a specialist there were was no difference to definitive treatment. There were no differences between treatment choices, consistent with the AJCC risk profiles between the two groups. Surprisingly, even after several interactions with medical specialists, more Maori did not attend follow up appointments than their counterparts (non attendance rate $13 \%$ vs $2 \%, p=0.02$ ). The reasons for non-compliance was not available, however, steps should be undertaken to overcome 
barriers faced by Maori; whilst the treating specialists should be aware of this issue when recommending post-orchidectomy treatment.

The major limitation of this study is the relatively smaller sample size and shorter follow up. The number of events were insufficient to examine differences in disease specific survival. In a larger study, it would be of interest to do a multivariate analysis to determine if greater non-compliance to treatment follow up led to poor survival. Data collection was also carried out retrospectively. Prospective studies could look at factors leading to poor compliance of Maori patients in this setting, whilst larger population based study may shed light into the disparate incidence rates (vide supra).

\section{Conclusion}

Maori men were more likely to develop testicular cancer within this study. Education amongst Maori men may be useful in reducing delay to seeking treatment and improving treatment compliance.

\section{Declarations}

Ethics approval: This study has been approved and registered with the Waikato District Health Board, Hamilton, New Zealand.

Consent to participate/publication: This study is a retrospective study involving human participants, but none of the participants were contacted nor identifiable. Informed consent is not applicable.

Availability of data and materials: The datasets analysed during the current study are available from the corresponding author on reasonable request.

Competing interests: The authors declare that they have no competing interests.

Funding: There was no funding associated with this study.

Conflict of Interests: All authors declare that they have no conflict of interests.

Authors' contributions: LL analyzed and interpreted patient data. MA provided the study concept. MA and $\mathrm{SN}$ was a major contributor in writing the manuscript. All authors read and approved the final manuscript. Acknowledgements: Not applicable

\section{References}

1. Shanmugalingam T, Soultati A, Chowdhury S, Rudman S, Hemelrijck M. Global Incidence and Outcome of Testicular Cancer. Clinical Epidemiology 2013:5,417 - 427

2. Ministry of Health. 2019. Wai 2575 Māori Health Trends Report. Wellington: Ministry of Health. 
3. Sarfati D, Shaw C, Blakely T, Atkinson J, Stanley J. Ethnic and socioeconomic trends in testicular cancer incidence in New Zealand. Int J Cancer 2011; 128: 1683 - 1691

4. Statistics New Zealand (2015). IDI Data Dictionary: 2013 Census data (November 2015 edition).

5. Gurney J, Sarfati D, Stanley J. Obscure etiology, unusual disparity: the epidemiology of testicular cancer in New Zealand. Cancer Causes Control 2015;26: 561 - 569

6. Huyghe E, Matsuda T, Thonneau P. Increasing Incidence of Testicular Cancer Worldwide: A Review. J Urol 2003; 170: 5 - 11

7. Richiardi L, Pettersson A, Akre O. Genetic and environmental risk factors for testicular cancer. Int J Androl 2007;30: 230 - 40

8. Gurney J. The puzzling incidence of testicular cancer in New Zealand: what can we learn? Andrology 2019;7: $394-401$

9. Manecksha R, Fitzpatrick J. Epidemiology of testicular cancer. BJU Int 2009;104: 1329- 1333.

10. Gurney J, Stanley J, McGlynn K, Richiardi L, Shaw C, Edwards R et al. Testicular Cancer in New Zealand (TCNZ) study: protocol for a national case-control study. BMJ Open 2018; 8(8): e025212

11. Ellison-Loschmann L, Pearce N. Improving Access to Health Care Among New Zealand's Maori Population. American Journal of Public Health 2006;96(4): 612 -617

12. Rahiri J, Alexander Z, Harwood M, Koea J, Hill A. Systematic review of disparities in surgical care for Maori in New Zealand. ANZ J Surg 2018;88: 683 - 689

\section{Figures}


16

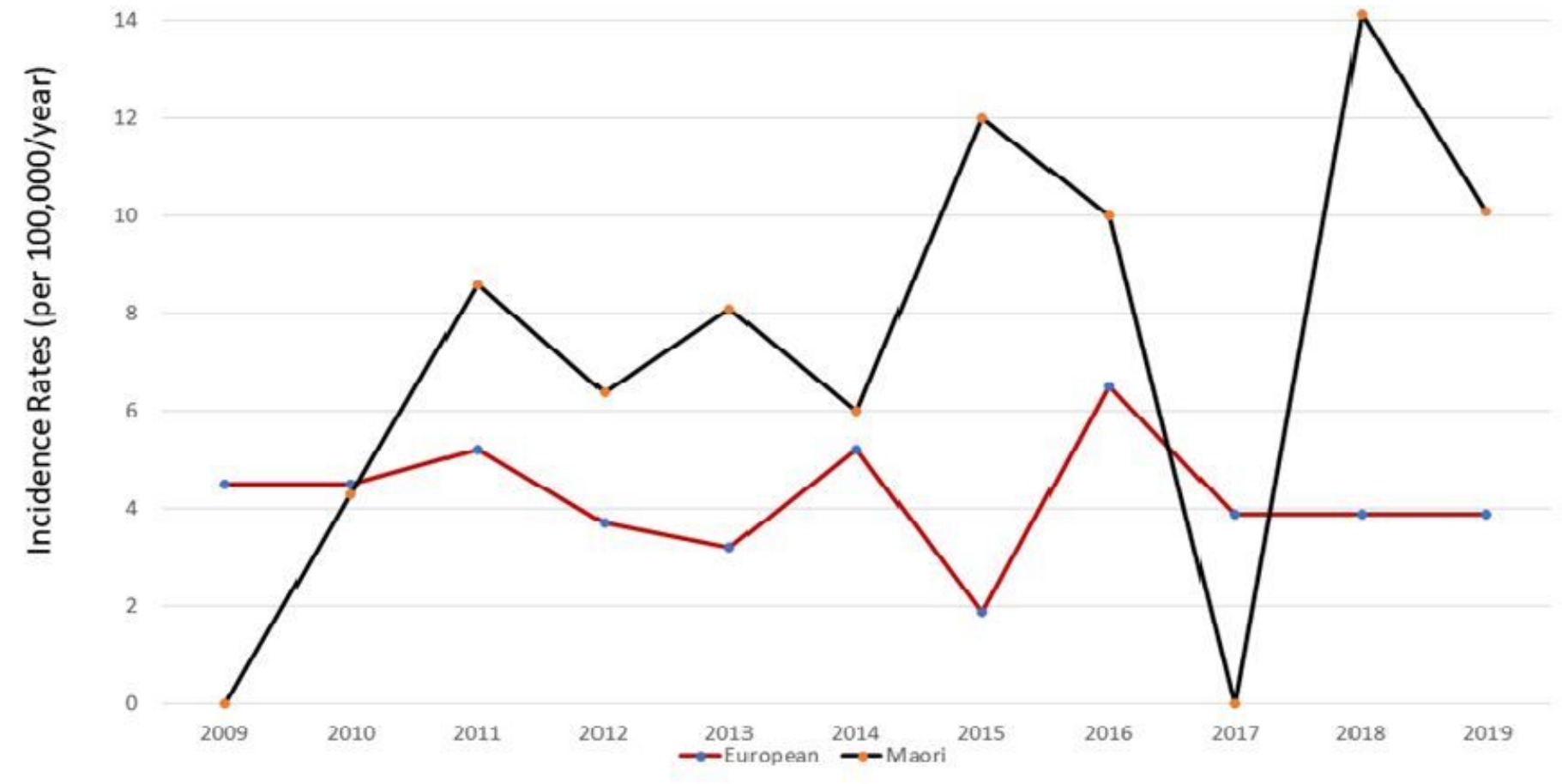

Figure 1

Incidence Rates from 2009 - 2019 for both Maori and European males 
16

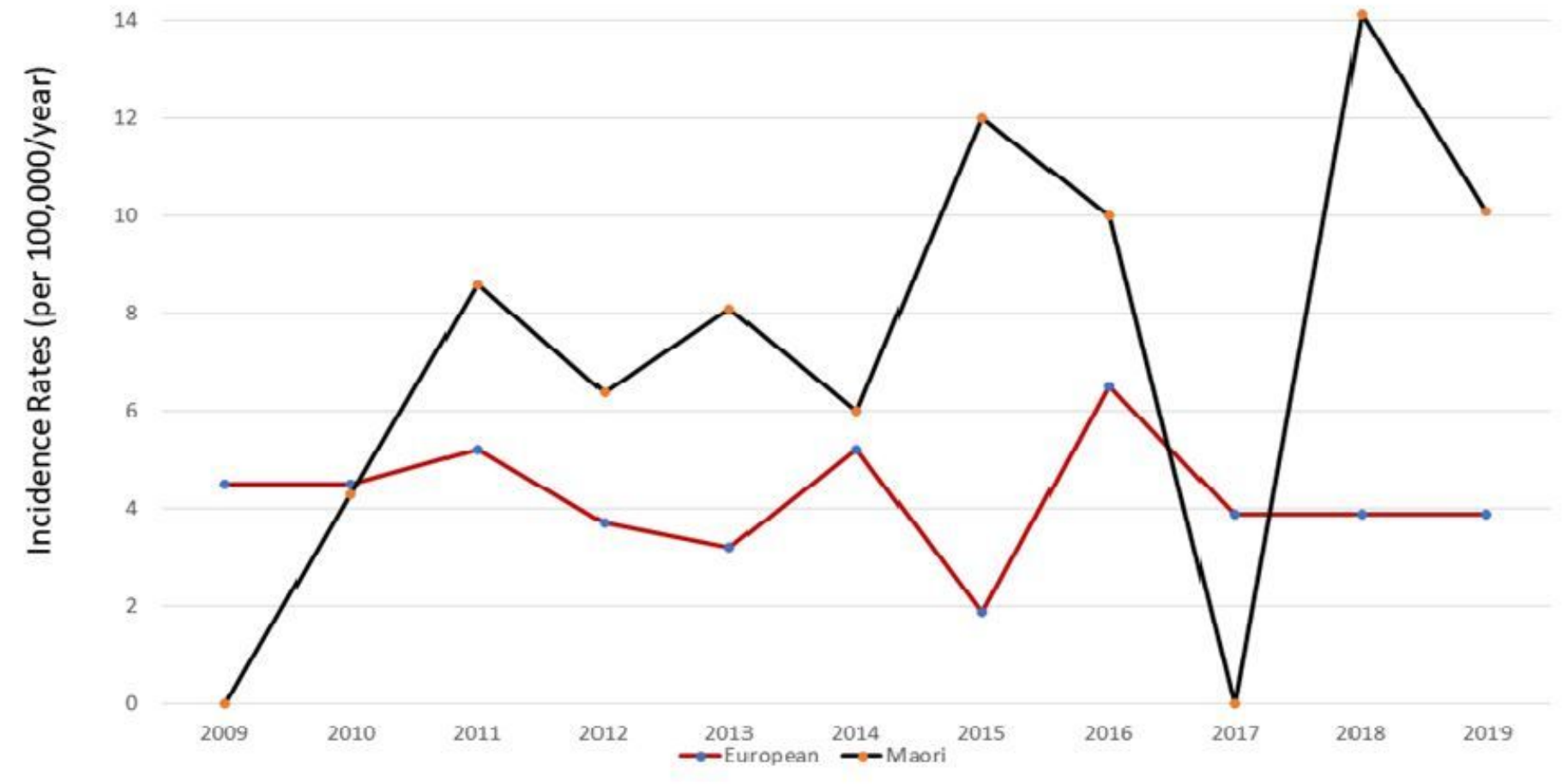

Figure 1

Incidence Rates from 2009 - 2019 for both Maori and European males 
16

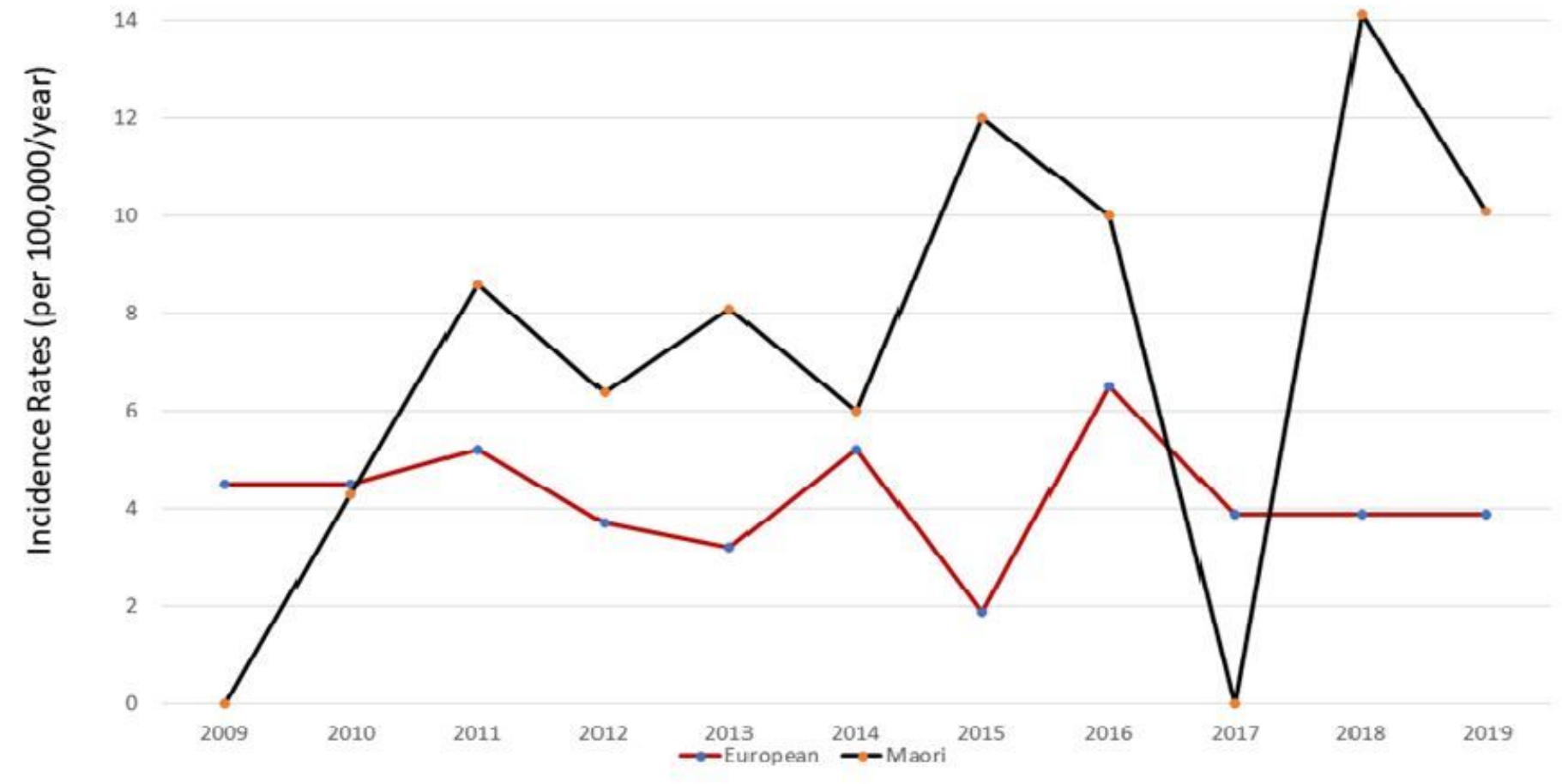

Figure 1

Incidence Rates from 2009 - 2019 for both Maori and European males 


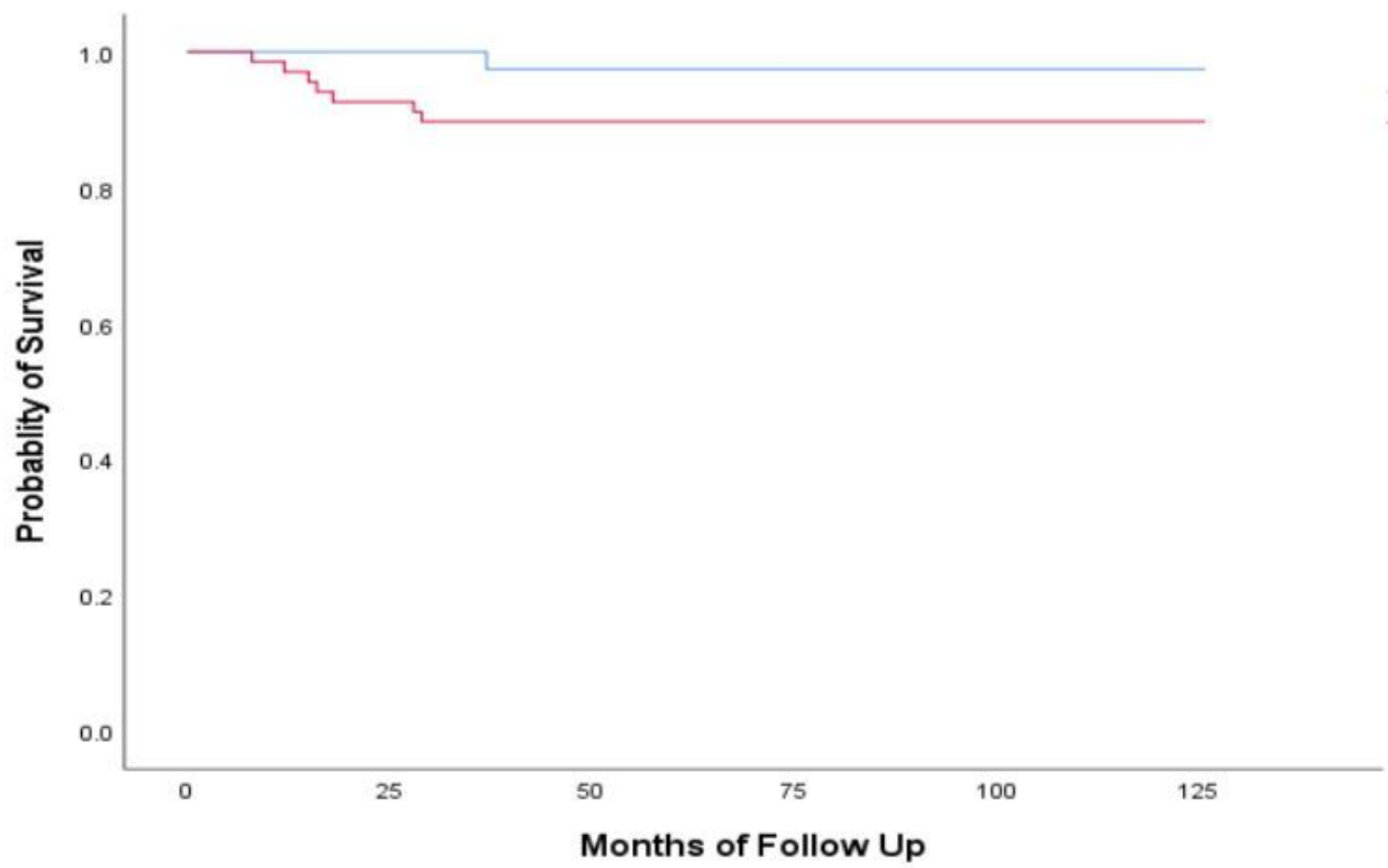

\section{Ethnicity}

$\neg$ Maori

$\neg$ European

Figure 2

Kaplan Meier curve comparing the 10 year overall-survival between Maori and European males 


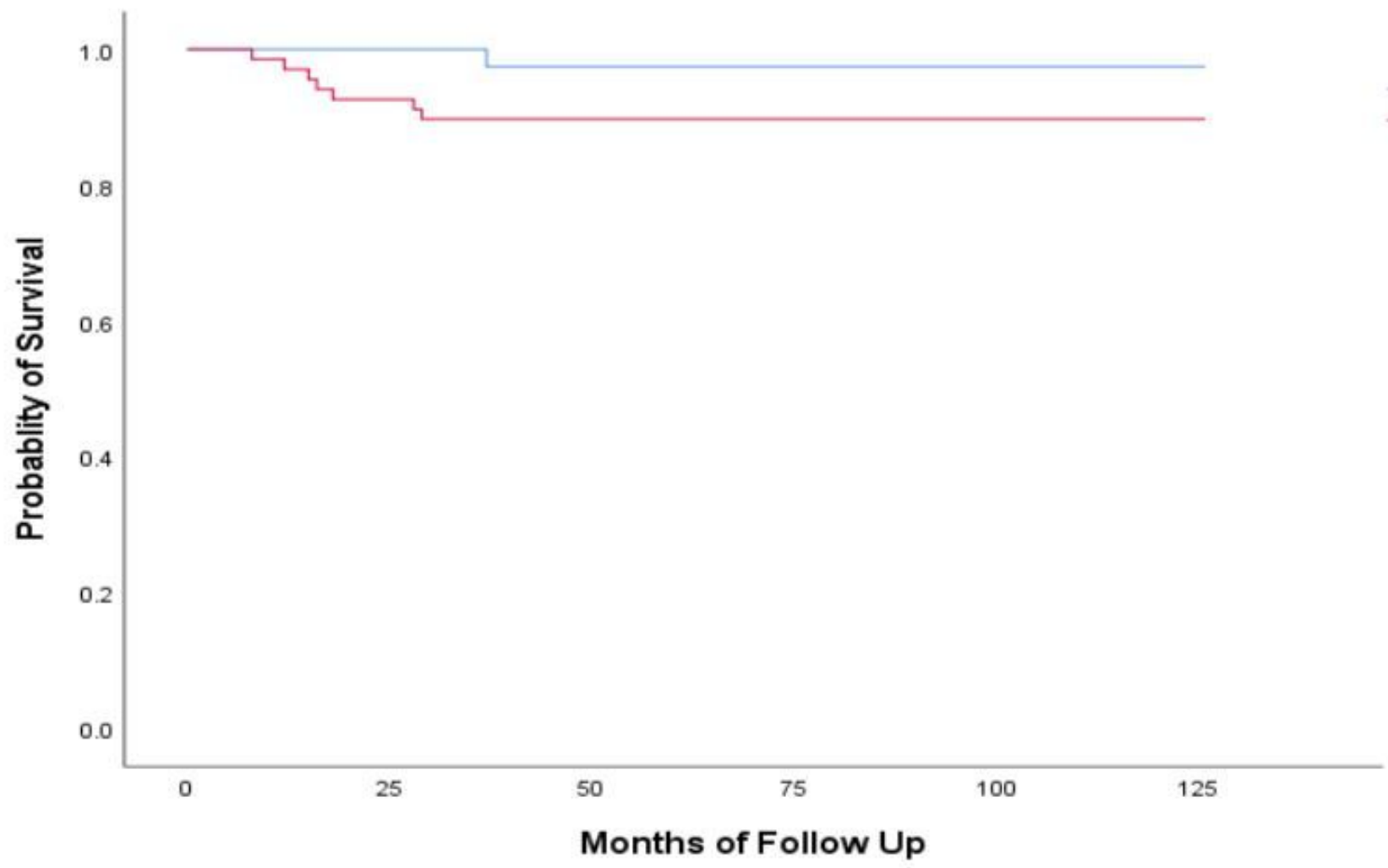

Ethnicity

$\longrightarrow$ Maori

$\neg$ European

Figure 2

Kaplan Meier curve comparing the 10 year overall-survival between Maori and European males 


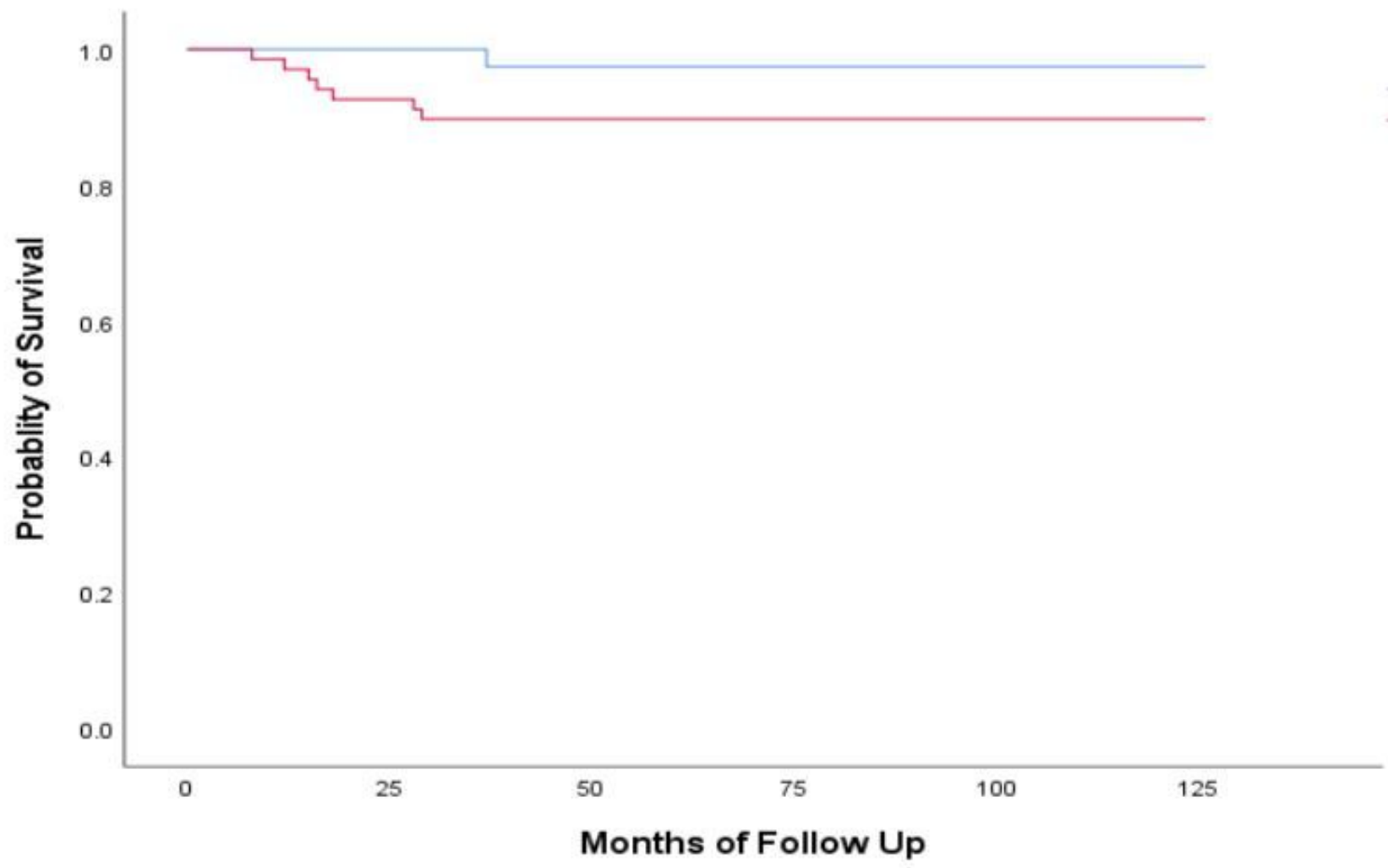

Ethnicity

$\longrightarrow$ Maori

$\neg$ European

Figure 2

Kaplan Meier curve comparing the 10 year overall-survival between Maori and European males 